\title{
The subjects of the offenses to the norms on safety and health at work and the social and organizational effects specific to companies conducting mining activities
}

\author{
Ioan Popescu ${ }^{1}$, Nicoleta-Monica Lohan ${ }^{2}$, Constantin Baciu ${ }^{2 *}$ Alin-Marian Cazac ${ }^{2}$, and \\ Elena-Raluca Baciu $^{3}$ \\ ${ }^{1}$ Territorial Labour Inspectorate, Neamț, dr. Gh. Iacomi St, 8, Neamț, Romania \\ ${ }^{2}$, ,Gheorghe Asachi” Technical University of Iasi, Bd. D. Mangeron 71A, 700050 Iaşi, Romania \\ 3 "Gr. T. Popa" University of Medicine and Pharmacy of Iasi, Romania, Faculty of Dental Medicine, \\ 16 University Street, 700115, Iasi - Romania
}

\begin{abstract}
The offenses concerning safety and health at work have no material object, their constitutive content including: the object and subject of the offense, the objective and subjective side of the offense. The active subjects of an offense have a legal obligation to apply and control the implementation of occupational safety and health measures and the passive subjects will bear the consequences of the occurrence of specific events. The existence of some uncertainties in the current legislation, also affecting mining companies, creates legal disputes especially in relation to the issues concerning active subjects. As for the passive subjects, the legal loophole refers to the situation of the day-labourers who may be involved in accidents at work and occupational illnesses. The authors consider it is necessary to formulate new law articles for clarification and even to draw up a future law with concrete reference to day-labourers, but also to some new risk sensitive social groups. Thus, the egal work relationships: the manner of performing the work, its remuneration and subordination to the beneficiary carrying out mining activities, will also be specified..
\end{abstract}

\section{Introduction}

Legal liability is one of the fundamental institutions of Law, with major implications for the life of every citizen. In the case of infringement of the regulations regarding the occupational safety and health and accidents at work, depending on the type of legal regulation infringed, on the degree of social danger entailed by the wrongful act, on the guiltiness of the culprit and on the social values prejudiced, there are several forms of legal liability: criminal, civil, contraventional, disciplinary, etc., the persons at fault (natural or legal) being liable for these legal responsibilities, depending on the type of criminal offenses committed.

In Romanian legislation the offenses related to occupational safety and health are danger criminal offenses. It is enough to create an imminent accident danger to attract

\footnotetext{
Corresponding author: constantin baciu@yahoo.com
} 
criminal liability, it is not necessary for the actual accident at work or occupational disease to occur, given that the content of the offense includes no references regarding the result. The state of danger is not provided for within the content of the offense and it is deduced from the very act of the deed.

\section{Criminal liability in case of infringement of regulations on safety and health at work and the occurrence of accidents at work}

Currently, this legal liability is provided for in two articles of Law no. 286/2009 Romanian Criminal Code [1]:

- Art. 349 - failure to take legal measures regarding safety and health at work;

- Art. 350 - failure to comply with occupational safety and health legal measures.

According to art. 349, paragraph 1 "in case an imminent danger of occurrence of an accident at work or of an occupational disease is created, the failure to take any of the legal measures regarding safety and health at work by the person in charge is punished by imprisonment from 6 months to 3 years or by a fine".

Art. 350, paragraphs 1 and 2 state the following:

- Paragraph 1: "Failure by any person to comply with the obligations and measures established regarding safety and health at work, in case it creates an imminent danger of a work-related injury or occupational disease, shall be punished by imprisonment from 6 months to 3 years or by a fine."

- Paragraph 2: "The same punishment shall be applied in case of recommissioning installations, machines and equipment before removing all the deficiencies for which the measure of stopping them was taken."

The constitutive content of offenses concerning occupational safety and health consists of:

- $\quad$ the object and subject of the offense;

- $\quad$ the objective and subjective side of the offense.

These offenses have no material. However, there are some authors [2] who claim that the material object of these offenses is the body of the person who suffers from a workrelated accident or from an occupational disease. Along with most of specialties $[3,4]$ we do not agree with this opinion, as these offenses can create an imminent danger without the events actually occurring. If an accident at work or an occupational disease occurs, then we shall find ourselves in the situation of a concurrence of offenses between: the offenses regarding the regulations on safety and health at work and those regarding injury or manslaughter, the latter having as material object the body of the victim. The Supreme Court of Romania ruled, by its criminal decisions no. 315/1974 [5] and 1475/1979 [6], that there is an ideal concurrence between the offense to the legal regime of safety and health at work and manslaughter.

\section{The subjects of the offenses to the norms on safety and health at work}

The subjects of offenses to the norms on safety and health at work, are:

- the persons involved in their doing, as active subjects;

- persons who bear the consequences of their occurrence, as passive subjects.

\subsection{Active subjects}


The legal content of the offense (Criminal Code, art. 349) refers to the person who, although was required to, did not take the occupational safety and health legal measures for any workplace. According to Law no. 319/2006 [7, 8] the persons responsible for taking legal measures are those who lead, organize and control the work processes. Therefore, the active subject of the offense provided for by art. 349 is a professionally qualified person with well-established obligations.

Art. 350, paragraph 1 of the Criminal Code states that the offense refers to any person's non-compliance with the obligations and measures regarding the safety and health at work. Paragraph 2 of article 350 refers to the persons who do not comply with the requirements regarding the recommissioning of installations, machines and equipment, before removing all the deficiencies for which the measure of stopping them was taken. Unlike the offense provided for by art. 349, when the active subject was a qualified person, the active subject of the offense provided for by art. 350 can be "any person" who does not abide by the conduct imposed by the specified regulation.

Law no. 319/2006 does not clearly specify who can be the active subjects of offenses related to safety and health at work.

By analysing separate provisions existing within this law, one can discuss the existence of a range of active subjects of offenses according to art. 5 of the law, which will include:

- the employer, the employees, the representatives of workers with specific responsibilities in the field of safety and health at work, the students and the pupils carrying out their internship, apprentices, other participants in the work process, persons who perform activities for the benefit of the community or volunteering activities, unemployed persons while participating in a form of vocational training, persons who do not have an individual employment agreement concluded in written form and for which the contractual provisions and the activities performed can be proved.

Art. 6 of Law no. 319/2006 specifies the following obligations:

a) the employer has the obligation to ensure the safety and health of workers in all aspects related to their work;

b) if he/she resorts to external services, the employer is not exempted from his responsibilities in the field;

c) workers have the obligation not to infringe the principle of employer responsibility.

By art. 8 of the Law, the employer may designate one or more workers to carry out occupational risks protection and prevention activities. In case of lack of competent staff, the employer will be able to resort to external services.

Subsequently, art. 22 and art. 23 of Law 319/2006 specify that each worker must carry out his/her activity in accordance with his/her training, as well as with the instructions received from the employer, in order not to expose to the dangers of accident or occupational illness both his/her own person, as well as other persons who may be affected by his/her actions or omissions during the work process. Where appropriate, all these obligations may also apply to the other participants in the work process, depending on the activities they carry out.

The interpretation of the provisions of art. 22 of Law 319/2006 and of art. 349 and art. 350 of the Criminal Code raised the question of the persons who can be considered active subjects of the offenses. Thus, in this category, there will be included only the persons having responsibilities in the field of safety and health at work, which are established by a document (contract, decision, job description, regulation, etc.) or also those who exercise certain tasks only in fact, without any official quality or valid written document. The practice of the Courts is non-unitary, as some $[9,10]$ consider that those persons who exercise management, coordination and control activities only in fact, should be excluded from the range of active subjects, while others $[11,12]$ consider that those persons who 
perform certain tasks only in fact, regardless of how they were invested, are also active subjects.

The authors consider that: both the person who has a legal obligation in this regard, as well as the person who performs in fact the duties in the field of occupational safety and health, can be the active subject of offenses regarding safety and health at work, regardless of how he/she was vested.

It should be noted that the active subject of offenses may also be a person who occasionally performs an activity in a workplace, or finds himself/herself at that workplace for different reasons [13], even if he/she does not perform permanently an activity in that workplace.

The person who, by exceeding his/her established work duties, infringes the occupational safety and health regulations, may also be an active subject of the same offenses, regardless of whether he/she is a member of the management or the execution staff, considering that he/she is actually exercising those duties [14].

\subsection{Passive subjects}

The passive subjects, in terms of occupational safety and health are:

- the state, as the main passive subject and holder of the protected social value;

- any natural person injured or endangered by committing the offenses, as a secondary passive subject. The passive subject's quality of employee is not a necessary condition for the existence of the offense, as a passive subject can be any person who was injured or was in imminent danger of being injured during the work process or in the performance of their duties.

\section{The quality of day workers}

In terms of offenses regarding safety and health at work, a special situation is created by the existence of day workers. Day workers are persons who perform activities in accordance with Law no. 52/2011 [15], which, by way of derogation from the provisions of the Labour Code, perform these activities on the basis of a labour relationship established by the will agreement of the parties (beneficiary and day worker) without the conclusion of an employment agreement, in written form. According to this law, the day worker does not have the quality of a person insured in the public insurance systems. In case of occurrence of an event that results in the accident/death of the day worker, the beneficiary is obliged to provide for the necessary expenses for medical care/burial from his own funds, if the event occurred due to the beneficiary's fault. The event is investigated by the Territorial Labour Inspectorate with jurisdiction in the area were the event occurred.

Following the analysis of the provisions of Law no. 52/2011, it is found that both the beneficiaries and the day workers can have the quality of active or passive subjects of offenses regarding occupational safety and health. In practice, during the investigation of these events, it is difficult to establish which legal or conventional provisions have been violated because the provisions of Law no. 319/2006 do not apply in these cases.

With regard to this situation of day workers, the authors consider that it is necessary to urgently amend the current legislation which, at one point, could be considered discriminatory on the labour market. Although they perform an activity according to Law no. 52/2011, the work relationship does not grant them the quality of a person insured in the public insurance systems. It is possible that, in case of an event that results in the accident or death of the day worker and which causes material and moral damages, these may remain partially or completely unrepaired. 
The same findings and proposals for legislative amendments are also valid for some new risk-sensitive social groups: elderly workers, migrant workers and temporary workers. Given that the lack of clarity in the current legislation on Labour Law, the Criminal Code and Law no. 319/2006 is affecting more and more people who perform work, it would be necessary to elaborate a lex ferenda specifying the legal work relationships: the manner of providing work, its remuneration and subordination to the employer.

The presented inconsistencies and legislative deficiencies affect all sectors of activity, both public and private. So, obviously, they can also affect the activities of mining companies.

The special conditions of an underground work environment, characterized by the action of numerous professional risk factors, prioritizes the improvement of the current legislation to mitigate the negative social and organizational effects specific to mining companies, in accordance with the occupational health and safety laws and regulations [1619].

\section{Conclusions}

Persons who, either under the Law no. 319/2006, or by virtue of work relationships, have the legal and/or conventional (contractual) obligation to take and apply - or to comply with, the measures or obligations regarding occupational safety and health, can be active subjects of offenses regarding safety and health at work.

There are legislative uncertainties that lead to contradictory judgments: some courts consider that the active subjects of the offenses regarding safety and health at work are only the persons having duties in the field of safety and health at work, established by a document. Other courts include in the range of the active subjects also those persons who exercise only in fact certain duties, regardless of how they were vested.

The authors' proposal is: both the person who has a legal obligation in this regard, as well as the person who performs in fact the duties in the field of occupational safety and health, can be the active subject of offenses regarding safety and health at work, regardless of how he/she was vested.

The active subjects of the offenses regarding occupational safety and health may also be the persons who: occasionally perform an activity in a work place, or the persons who, by exceeding their duties, violate occupational safety and health regulations.

A special situation in term of committing offenses regarding occupational safety and health is created by the existence of day workers. They perform an activity based on Law no. 52/2011, but are not included in the provisions of Law no. 319/2006 in case of accidents at work or occupational diseases.

In the case of day workers, it is necessary to urgently amend the current legislation in order to grant them the quality of persons insured in the public insurance systems, thus benefiting from the provisions of Law no. 319/2006 in the event of work accidents or occupational diseases.

In order to address the issues of the day workers and those of the new risk-sensitive social groups, a lex ferenda should be elaborated, that shall also specify the atypical legal work relationships existing for these persons.

\section{References}

1. *** Legea nr. 286/2009 privind Codul penal

2. R. R. Popescu, Dreptul penal al muncii, (Ed. Wolters Kluwer, Bucureşti 2008)

3. I.M. Aron, (Accidentul de muncă, Ed. Universul Juridic,Bucureşti 2014) 
4. St. Boboc, Cod penal, Rev. Română de Dreptul Muncii, 2, p. 39 (2015)

5. *** Decizia nr. 315/1974 a Tribunalului Suprem al României

6. *** Decizia nr. 1475/1979 a Tribunalului Suprem al României

7. *** Legea nr. 319/2006 a Securităţii și Sănătății în Muncă

8. *** H.G 1425/2006 pentru aprobarea Normelor metodologice de aplicare a prevederilor Legii securității și sănătății in munca nr. 319 din 2006

9. *** Decizia penală nr. 125/2013, Curtea de Apel Bacău

10. T.C. Medeanu, Revista Dreptul 5, p. 116 (1999)

11. *** Sentința penală nr. 1169/2012, Judecătoria Bacău

12. *** Sentința penală nr. 55/1979, Judecătoria Deva

13. *** Decizia nr. 13/1966 a Plenului Tribunalului Suprem, în Culegere de Decizii ale Tribunalului Suprem pe anul 1966, Ed. Ştiinţifică, Bucureşti, (1967)

14. *** C. Buga (Protecţia muncii, Ed. Ştiinţifică şi Enciclopedică, 1980)

15. *** Legea nr. $\mathbf{5 2 / 2 0 1 1}$ privind exercitarea unor activităţi cu caracter ocazional desfăşurate de zilieri

16. C. Bejinariu, D.-C. Darabont, E.-R. Baciu, I.-S. Georgescu, M.-A.Bernevig-Sava, C. Baciu, Sustainability, 9, p. 1263 (2017)

17. C. Bejinariu, D.C. Darabont, E.R. Baciu, I. Ionita, M.A.B. Sava, C. Baciu, Environ. Eng. Manag. J., 16, pp. 1395-1400 (2017)

18. D.-C. Darabont, R.I. Moraru, A.E. Antonov, C.Bejinariu, Qual.-Access Success, 18, pp. 11-14, (2017)

19. D.C. Darabont, A.E. Antonov, C. Bejinariu, In 8th International Conference on Manufacturing Science and Education (MSE 2017) - Trends in New Industrial Revolution, Bondrea, I., Simion, C., Inta, M., Eds., E D P Sciences: Cedex A, 121, p. UNSP 11007 (2017) 